\title{
A new species of Choleoeimeria (Apicomplexa: Eimeriidae) from Oustalet's chameleon, Furcifer oustaleti (Sauria: Chamaeleonidae)
}

\author{
Chris T. McAllister
}

Science and Mathematics Division, Eastern Oklahoma State College, Idabel, Oklahoma 74745, USA

\begin{abstract}
One of three (33\%) captive specimens of Oustalet's chameleon, Furcifer oustaleti (Mocquard) originally from Madagascar and housed at the Oklahoma City Zoological Park Herpetarium, Oklahoma County, Oklahoma, USA, was found to be passing an undescribed species of Choleoeimeria in its faeces. Oocysts of Choleoeimeria fischeri sp. n. were cylindroidal, $30.3 \times 16.8$ (28-34 $\times 15-18) \mu \mathrm{m}$, with a smooth, bilayered wall and a length/width ratio (L/W) of 1.8. A micropyle and oocyst residuum was absent but a fragmented polar granule was often present. Sporocysts were ovoidal, $9.6 \times 8.0(9-10 \times 7-9) \mu \mathrm{m}$, with an L/W of 1.2. Stieda, sub-Stieda, and para-Stieda bodies were absent. The sporocyst residuum consists of large globules dispersed between sporozoites. Sporozoites were elongate, $8.6 \times 2.9(8-10 \times 2-3) \mu \mathrm{m}$, with an elongate posterior refractile body. The new species represents the second coccidian described from this lizard.
\end{abstract}

Keywords: Coccidia, Choleoeimeria, Furcifer oustaleti, Oustalet's chameleon, taxonomy

The Malagasy giant chameleon or Oustalet's chameleon, Furcifer (= Chamaeleo) oustaleti (Mocquard, 1894) is a very large species (maximum length $=68.5 \mathrm{~cm}$ ) that is endemic to Madagascar (LeBerre et al. 2000, Glaw and Vences 2007). It may be found in a wide variety of habitats, most often among degraded areas and agricultural land and human settlements, but also occurs in undisturbed dry forest, montane savannah and, rarely, in tropical rainforest. Its diet includes a variety of invertebrates, especially large insects (LeBerre et al. 2000).

Little is known about the coccidian parasites of $F$. ous taleti. Brygoo (1963) reported endogenous stages of a gall-bladder eimerian from $F$. oustaleti which fit characteristics of the genus Choleoeimeria (sensu Paperna et Landsberg 1989) but, unfortunately, did not provide a formal description. In addition, he (Brygoo 1963) provided information on an eimerian from $F$. oustaleti showing stages in intestinal epithelium but, again, did not provide a formal description. These have been variously referred to as Eimeria sp. 1 and Eimeria sp. 2 of Brygoo, 1963, respectively, on the Coccidia of the World website (http:// www.biology.unm.edu/biology/coccidia/home.html). A figure of both unsporulated and sporulated oocysts of an unknown eimerian (possibly Choleoeimeria) from F. oustaleti was provided by Will (1975, fig. 2). Modrý et al. (2001a) described Eimeria worthi Modrý, Daszak, Volf, Veselý, Ball et Koudela, 2001 from a single $F$. oustaleti imported from Madagascar by a pet trader. Nothing else, to my knowledge, has been published on coccidia from this lizard. Herein I provide a description of a new species of Choleoeimeria from F. oustaleti.

\section{MATERIALS AND METHODS}

During February 1993, fresh faeces from three captive adult F. oustaleti chameleons housed in quarantine at the Oklahoma City Zoological Park Herpetarium (OCZPH) in Oklahoma City, Oklahoma, were collected for examination of coccidia. These chameleons had originated from an unknown locality in Madagascar. Samples were placed in individual vials containing 2.5\% $(\mathrm{w} / \mathrm{v})$ aqueous potassium dichromate $\left(\mathrm{K}_{2} \mathrm{Cr}_{2} \mathrm{O}_{7}\right)$ and examined for coccidia by light microscopy after flotation in Sheather's sugar solution (specific gravity $=1.18$ ). A single sample contained fully sporulated oocysts and measurements were taken on 25 oocysts using a calibrated ocular micrometer and reported in micrometres $(\mu \mathrm{m})$ as the means followed by the ranges in parentheses; photographs were taken using Nomarski interference-contrast optics. Oocysts were $\sim 60$ days old when measured and photographed. Descriptions of oocysts and sporocysts follow guidelines of Wilber et al. (1998) as follows: oocyst length (L) and width (W), their ranges and ratios (L/W), micropyle (M), oocyst residuum (OR), polar granules (PG), sporocyst length $(\mathrm{L})$ and width $(\mathrm{W})$, their ranges and ratio $(\mathrm{L} / \mathrm{W})$, Stieda body (SB), sub-Stieda body (SSB), para-Stieda body (PSB), sporocyst residuum (SR), sporozoites (SP), refractile bodies (RB), and nucleus (N). Voucher specimens of $F$. oustaleti were originally accessioned into the OCZPH as Nos. 5524-19, 5766-23, and 5816-25. Phototypes of sporulated oocysts were accessioned into the United States National Parasite Collection (USNPC), Beltsville, Maryland, USA. Lizard taxonomy follows the TIGR reptile database (Uetz 2011).

Address for correspondence: C.T. McAllister, Eastern Oklahoma State College - Science and Mathematics Division, 2805 NE Lincoln Rd., Idabel, Oklahoma 74745, United States. Phone: +1 5803765239; Fax: +1 5803765260; E-mail: cmcallister@se.edu 

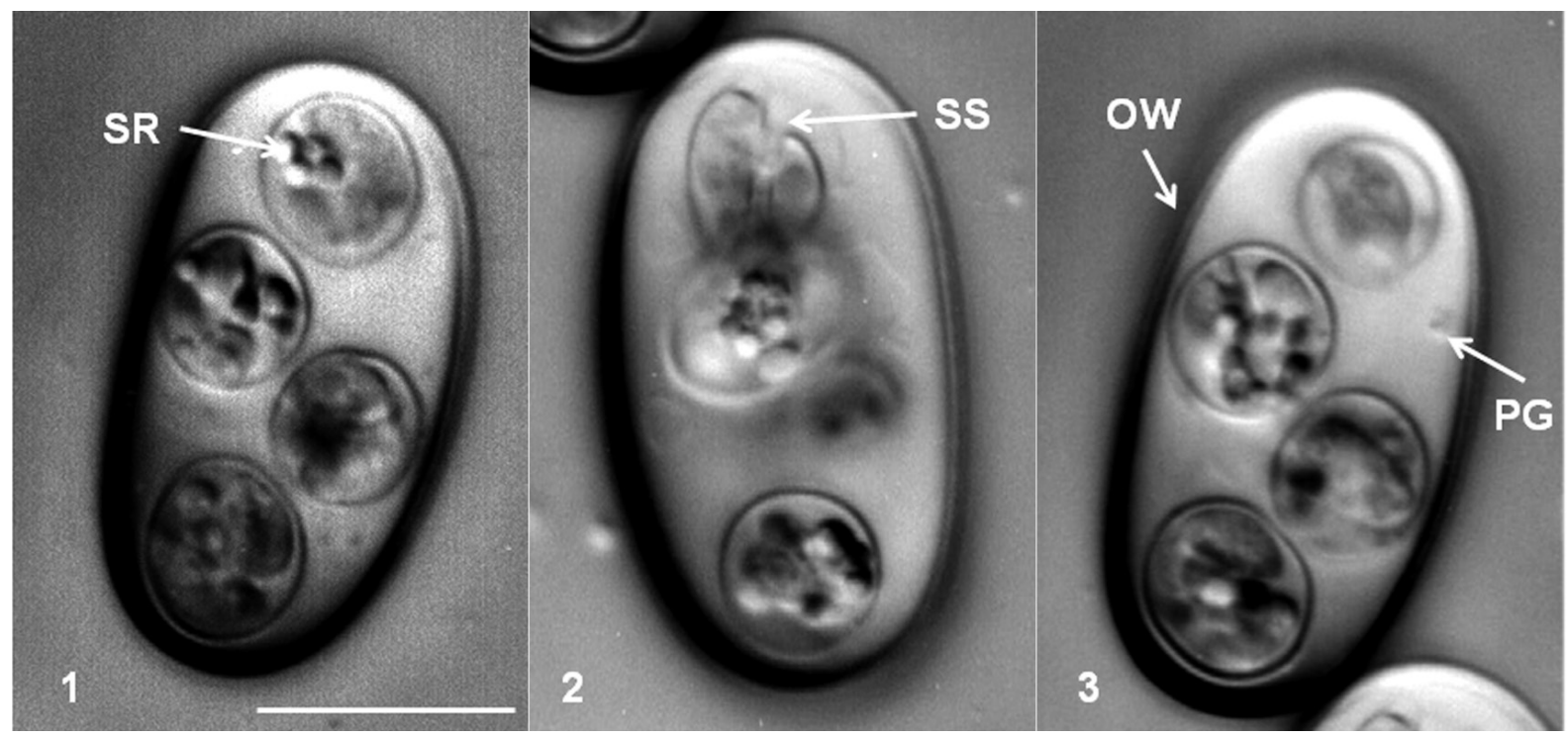

Figs. 1-3. Choleoeimeria fischeri sp. n., Nomarski interference-contrast photomicrographs of oocysts. Fig. 1. Sporocyst residuum (SR). Fig. 2. Sporocyst suture (SS). Fig. 3. Oocyst wall (OW); polar granule (PG). Scale bar for all figures $=10 \mu \mathrm{m}$.

\section{RESULTS}

One of three (33\%) F. oustaleti was found to be passing oocysts of an undescribed species of Choleoeimeria. The description follows:

\section{Choleoeimeria fischeri sp. n.}

Figs. 1-4

Description (based on 25 sporulated oocysts): Oocyst shape cylindroidal; bilayered wall, $\sim 1.0$ thick, smooth outer layer $\sim 0.5$, inner layer $\sim 0.5 ; \mathrm{L} \times \mathrm{W} 30.3 \times 16.8$ (28-34 × 15-18); L/W 1.8 (1.6-2.1). M and OR absent; PG present, often fragmented. Sporocysts $(\mathrm{SP})(\mathrm{n}=20)$ ellipsoidal, L × W $9.6 \times 8.0(9-10 \times 7-9)$; L/W $1.2(1.1-$ 1.3); smooth single-layered wall $\sim 0.5$ thick; SB, SSB and PSB absent; SR $(n=20)$ spherical or subspherical, $4.6 \times$ $4.2(4-5 \times 3-5)$ composed of 10-12 large globules. SP $(\mathrm{n}=10)$ elongate, $\mathrm{L} \times \mathrm{W} 8.6 \times 2.9(8-10 \times 2-3)$ in situ, lying along one side of sporocyst. Each SP with ellipsoidal posterior RB $(n=10), 3.0 \times 2.4(2-3 \times 2-3)$; single $N$ slightly posterior to midpoint of body.

Type and only host: Furcifer (= Chamaeleo) oustaleti (Mocquard), the Malagasy giant or Oustalet's chameleon (Sauria: Chamaeleonidae); adult female No. 5524-19, weight $=230 \mathrm{~g}$. Individual died of hepatitis on 18 August 1993 .

Type locality: Madagascar, detailed locality unknown.

Site of infection: Unknown, probably gall bladder (tissue samples were not available for histological examination).

Prevalence: 1 of $3(33 \%)$ of the chameleons was found to be passing oocysts.

Sporulation: Endogenous. All oocysts were passed in the faeces fully sporulated. Prepatent and patent periods unknown.

Specimens deposited: Photosyntypes deposited as USNPC 104878.

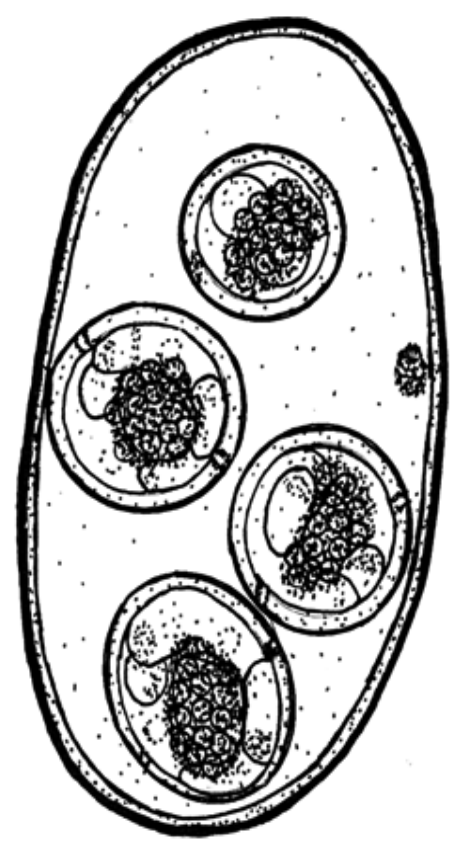

$10 \mu \mathrm{m}$

Fig. 4. Choleoeimeria fischeri sp. n., composite line drawing of oocyst.

Etymology: The specific epithet is given in honour of Johann von Fischer (1850-1901), former Director of the Düsseldorf Zoo and the Laboratorie d'Erpétologie in Montpelier, for his studies on chameleons (see Murphy 2005).

Remarks. Oocysts of Choleoeimeria fischeri sp. n. can be easily distinguished from the only other coccid- 
ian (Eimeria worthi) previously described from $F$. oustaleti (Modrý et al. 2001a) as they are considerably larger $(30.3 \times 16.8$ vs. $17.9 \times 15.0 \mu \mathrm{m})$ and have a cylindrical $(\mathrm{L} / \mathrm{W}=1.8)$ vs. spherical shape $(\mathrm{L} / \mathrm{W}=1.2)$. However, oocysts and sporocysts of the new species are most similar to Choleoeimeria tilburyi from Jackson's chameleon, Chamaeleo jacksonii from Kenya (Modrý et al. 2000) but possess a considerably smaller sporocyst L/W (1.2 [1.11.3] vs. 1.5 [1.3-1.7]). Interestingly, although Will (1975) did not provide measurements of the unnamed eimerian from $F$. oustaleti, the L/W of oocysts (calculated from his photomicrograph) averaged $\sim 1.9(1.8-2.0)$, which is within the range of the new species. In addition, the new species differs from other eimerians described by Modrý et al. (2000, 2001a, b) and Sloboda and Modrý (2006, see their table 1) from East African and Madagascar chameleons. To my knowledge, no other lizard eimerian has been described with a combination of characters descriptive of the new species.

\section{DISCUSSION}

The separate status of Choleoeimeria Paperna et Landsberg, 1989, as a sister clade to the Eimeriidae was confirmed by phylogenetic analysis (small subunit rRNA gene) by Jirků et al. (2002). In addition, a taxonomic revision of tetrasporocystic coccidia from chameleons was provided by Sloboda and Modrý (2006). In that report, these authors provided new combinations of taxa originally described as Eimeria spp. from various chameleons (Sloboda and Modrý 2006, table 1), and, subsequently their reclassification in the genus Choleoeimeria was 3-fold as follows: (1) those species infecting the biliary epithelium, (2) those possessing cylindrical oocysts, and (3) those with sporocyst sutures. Therefore, these appear to be distinct oocyst and sporocyst features of Choleoeimeria (see also Modrý and Jirků 2006) and, as such, the new species, which possesses all three features, is placed in this genus rather than Eimeria. However, some (Daszak et al. 2009) have not adopted this classification and suggest that designation of a species to either genus requires examination of the endogenous stages or molecular studies. Therefore, future studies on Choleoeimeria fischeri should involve histological examination of endogenous stages in the gall bladder epithelium and/or molecular analyses.

Acknowledgements. I thank David Grow, former Curator of Herpetology (OCZPH), for providing faecal samples from chameleons under his care for examination, and Don Whitten, Registrar $(\mathrm{OCZPH})$ for detailed information on these captive chameleons. Further appreciation is extended to Patricia A. Pilitt (USNPC) for expert curatorial assistance. Lastly, I express my sincere appreciation to the late Dr. Steve J. Upton (1953-2010), who provided detailed information relating to the new species.

\section{REFERENCES}

BRYGOO E.R. 1963: Contribution à la connaissance de la parasitologie des Caméléons malgaches. Ann. Parasitol. Hum. Comp. 38: 525-739.

Daszak P., Ball S.J., Jones C.G., Streicker D.G., Snow K.R. 2009: Six new species of coccidia (Apicomplexa: Eimeriidae) from endangered Phelsuma spp. geckoes (Sauria: Gekkonidae) of the Black River Gorges National Park, Mauritius. Folia Parasitol. 56: 233-241.

Glaw F., Vences M. 2007: A Fieldguide to the Amphibians and Reptiles of Madagascar. 3rd Edition. M. Vences and F. Glaw Verlags, Köln (Cologne), 496 pp.

Jirkư M., Modrý D., Šlapeta J.R., Koudela B., Lukeš J. 2002: The phylogeny of Goussia and Choleoeimeria (Apicomplexa: Eimeriorina) and the evolution of excystation structures in coccidia. Protist 153: 380-389.

LeBerre F., Bartlett R.D., Bartlett P. 2000: The Chameleon Handbook. Barron's Educational Series. Hauppauge, New York, USA, $144 \mathrm{pp}$.

Modrý D., Daszak P., Volf J., Veselý M., Ball S.J., KoudeLA B. 2001a: Five new species of coccidia (Apicomplexa: Eimeriidae) from Madagascan chameleons (Sauria: Chamaeleonidae). Syst. Parasitol. 48: 117-123.

ModrÝ D., JiRKŮ M. 2006: Three new species of coccidia (Apicomplexa: Eimeriorina) from the Marble-throated skink, Marmorosphax tricolor Bavay, 1869 (Reptilia: Scincidae), endemic to New Caledonia with a taxonomic revision of Eimeria spp. from scincid hosts. Parasitol. Res. 99: 416-428.
Modrý D., Šlapeta J.R., Koudela B. 2000: Six new species of coccidia (Apicomplexa: Eimeriidae) from East African chameleons (Sauria: Chamaeleonidae). J. Parasitol. 86: 373-379.

Modrý D., Šlapeta J.R., Koudela B. 2001b: Eimeria hajeki n. sp. (Apicomplexa: Eimeriidae), a new coccidian parasite of the pygmy chameleon, Rampholeon temporalis (Matschie, 1892) (Reptilia: Chamaeleonidae) from Usambara Mountains, Tanzania. J. Parasitol. 87: 1104-1105.

Murphy J.B. 2005: Chameleons: Johann von Fischer and other perspectives. SSAR Herpetol. Circ. 33, 123 pp.

Paperna I., Landsberg J.H. 1989: Description and taxonomic discussion of eimerian coccidia from African and Levantine geckoes. S. Afr. J. Zool. 24: 345-355.

Sloboda M., Modrý D. 2006: New species of Choleoeimeria (Apicomplexa: Eimeriidae) from the veiled chameleon, Chamaeleo calyptratus (Sauria: Chamaeleonidae), with taxonomic revision of eimerian coccidia from chameleons. Folia Parasitol. 53: 91-97.

Uetz P. 2011: The TIGR Reptile Database. http://www.reptiledatabase.org/. (Accessed 14 September 2011).

Wilber P.G., Duszynski D.W., Upton S.J., Seville R.S., CorLISS J.O. 1998: A revision of the taxonomy and nomenclature of the Eimeria spp. (Apicomplexa: Eimeriidae) from rodents in the Tribe Marmotini (Sciuridae). Syst. Parasitol. 39: 113-135.

WiLl R. 1975: Die Entstehungsursachen (Ätiologie) der Lebererkrankungen bei Reptilien. Zbl. Vet. Med. B 22: 626-634. 